Удк 371.315.6:51

Оксана Дубинська

Сумський державний педагогічний університет імені А. С. Макаренка ORCID ID 0000-0001-7088-3484

Ольга Мариченко

Сумський державний педагогічний університет імені А. С. Макаренка ORCID ID 0000-0002-1262-3120

Анастасія Бєля

Сумський державний педагогічний університет імені А. С. Макаренка ORCID ID 0000-0002-4413-4882

DOI 10.24139/2312-5993/2019.08/054-066

\title{
ВПЛИВ РЕКРЕАЦІЙНО-ОЗДОРОВЧОЇ ПРОГРАМИ НА ФІЗИЧНУ ПІДГОТОВЛЕНІСТЬ ТА ПСИХІЧНИЙ СТАН ДІВЧАТ СТАРШОЇ ШКОЛИ НА ОСНОВІ ЗАСТОСУВАННЯ МЕНТАЛЬНОГО ФІТНЕСУ
}

Розроблено оздоровчо-рекреаційну програму занять на основі застосування засобів ментального фітнесу, спрямовану на корекцію фізичної підготовленості та поліпшення психічного стану дівчат старшої школи. Методи: аналіз та узагальнення науково-методичної літератури, психолого-педагогічні методи, педагогічний експеримент, тестування, методи математичної статистики. Нами вивчено вплив розробленої програми на розвиток рухових здібностей старшокласницями й досліджено особливості проектування їх життєвих перспектив. Під впливом занять за розробленою оздоровчо-рекреаційною програмою на основі застосування засобів ментального фітнесу відбулися статистичновірогідні позитивні зміни в їх ставленні до власного тілесного потенціалу, а також у показниках фізичної підготовленості старшокласниць.

Ключові слова: старшокласничі, рекреачійно-оздоровча програма, ментальний фрітнес, рухові здібності, саморефлексія тілесного потенціалу.

Постановка проблеми. Проаналізувавши наукову та методичну літературу, можна свідчити, що рухова діяльність учнів старшої школи має тенденцію до зниження. Інтенсифікація навчальної діяльності школярів, види діяльності, у яких обмежена рухова активність (перегляд фільмів, комп'ютерні розваги, прослуховування музичних композицій) тісно пов'язані з гіпокінезією в дітей, що набуває розвитку в останній час. Таким чином, у школярів збільшується статичне напруження під час роботи постійної інтенсивності, з'являється дефіцит м'язової діяльності.

У той самий момент науковцями (Круцевич, 2019; Шевців, 2009; Павленко, 2016) досліджено, що за рахунок втрати інтересу та 
зацікавленості до уроків фізичної культури та загалом негативного відношення до спортивної діяльності знижується рухові здібності школярів.

На сьогодні, за фізичний розвиток та здоров'я дітей відповідає шкільна програма фізичного виховання. Але відомо, що уроки фізичної культури не взмозі повністю забезпечити необхідний рівень рухової діяльності учня та потрібного рухового ефекту.

Відносно до цього, потрібно більш поширенно використовувати всі можливості шкільної програми фізичної культури для забезпечення максимального розвитку фізичної діяльності, рухових здібностей, зміцнення здоров'я та популяризації здорового способу життя серед учнів старших класів. Особливе місце в системі шкільного навчання займає старший шкільний вік, оскільки в цьому віці відбувається особистісне становлення учня, побудова життєвого плану, постановка цілей на майбутню особистісну та професійну самореалізацію (Дубинська, 2016; Круцевич, 2019; Кренделєва, 2015).

Період навчання перед серйозними іспитами характеризується великим емоціональним стресом. Весь вільний час старшокласники займаються навчанням у сидячому положенні, ведуть малорухливий образ життя, запам'ятовуть велику кількість інформації, постійно знаходяться в стресовій ситуації. Підготовка до серйозних іспитів приводить нервову систему школярів у стан напруги, що негативно позначається на їх психічному здоров'ї. Результатами такого перенапруження $€$ сонливість, розгубленість, нервові зриви, що тільки ускладнюють складний період життя. Під час підготовки до ЗНО сучасним старшокласникам доводиться стикатися з великою кількістю труднощів і перешкод. У даний час збільшилася кількість тривожних учнів, що відрізняються підвищеним занепокоєнням, непевністю, емоційною нестійкістю (Ігонін, 2014). Для того, щоб відкорегувати фізичний і психоемоційний стан школярів, необхідні фізичні навантаження, що позитивно впливатимуть як і на фізичне, так і на психічне розслаблення учнів.

Натомість саме інтеграція ментального фітнесу та аеробіки, на нашу думку, може сприяти поліпшенню функціонального та психофізичного стану жінок першого зрілого віку, удосконаленню їх фізичної підготовленості, підвищенню розумової працездатності, урівноваженню емоційно-вольової сфери, а отже, досягненню гармонійного фізичного, психічного та духовного стану.

Роботу виконано відповідно до плану науково-дослідної роботи кафедри теорії та методики фізичної культури Сумського державного педагогічного університету імені А. С. Макаренка Міністерства освіти і науки України за темою «Підвищення рівня здоров'я і фізичної підготовленості різних груп населення засобами фізичної культури» (номер державної реєстрації 0111 U 005736) на 2011-2015 рр. 
Аналіз актуальних досліджень. Окремими науковцями було розроблено авторські методики для покращення фізичної підготовленості старшокласниць та підвищення рівня їх рухової активності засобами оздоровчих видів гімнастики (Шевців, 2019; Кренделєва, 2015); для корекції ваги тіла дівчат старшого віку на основі застосування засобів оздоровчого фітнесу (Павленко, 2016). Заслуговує на увагу авторська методика побудови індивідуальних фітнес-програм старшокласниць у процесі самостійних занять фізичними вправами (Ващук, 2016).

Окремо заслуговує на увагу робота Т. Синиці (2019), у якій розглядалася корекція фізичного стану жінок першого зрілого віку засобами оздоровчої аеробіки та ментального фітнесу. Але в її дослідженні не було приділено уваги розробленню та обґрунтуванню індивідуальних програм занять ментальним фітнесом різного цільового спрямування, у яких були би враховані параметри навантаження залежно від рівня фізичного стану та пріоритетних мотивів дівчат старшої школи.

У роботі О. В. Андрєєвої (2015) розроблена програма рекреаційнооздоровчої діяльності з метою спрямування на задоволення дозвіллєвих потреб різних груп населення, збільшення обсягу рухової активності та якісного наповнення їх вільного часу, але в їі роботі не було запропоновано відповідних методик для учнів старшої школи, які би позитивно впливали на їх фізичний та психоемоційний стан. Заслуговують на увагу роботи, що стосуються висвітлення основних тенденцій та напрямів міжнародного досвіду рекреаційної діяльності школярів. У цьому контексті цікавим $\epsilon$ наукове дослідження Т.Ю.Круцевич (2019), у якому проаналізовано й узагальнено вітчизняні та зарубіжні літературні джерела 3 проблем організації оздоровчо-рекреаційної діяльності учнівської молоді в закладах позашкільної освіти.

Таким чином, детальний аналіз науково-методичної літератури засвідчив необхідність розробки оздоровчо-рекреаційної програми, на основі застосування засобів ментального фітнесу, спрямовану на корекцію фізичної підготовленності та поліпшення психоемоційного стану старшокласниць.

Метою досліджень $є$ розробка оздоровчо-рекреаційної програми для корекції фізичного та психоемоційного стану дівчат старшої школи.

Для досягнення мети й розв'язання задач наукового дослідження застосовувалися такі методи: вивчення та узагальнення науково-методичної літератури, педагогічний експеримент, педагогічне спостереження, психолого-педагогічні методи, тестування, методи математичної статистики.

Виклад основного матеріалу. За останні роки та до сьогоднішнього дня спостерігається тенденція погіршення рівня здоров'я дітей старшої школи. Стреси, малорухомий спосіб життя мають великий вплив на організм дитини. Незадовільна організація процесу фізичного виховання у школі призводить як до нерегулярного відвідування уроків фізичної 
культури, так і до зниження мотивації до спортивних та фізкультурнооздоровчих занять.

Аналіз факторів, що обумовлюють виникнення в учнів старшої школи різних патологічних станів, свідчить про недоліки фізичного виховання в школі та позашкільних формах роботи, що впливають на стан здоров'я та фізичну підготовленість старшокласників.

Зважаючи на вищевикладене, нами було розроблено оздоровчорекреаційну програму, яка має вплив на фізичний та психоемоційний стан дівчат старшої школи 15-17 років на основі застосування засобів ментального фітнесу з урахуванням мотиваційних пріоритетів, фізичної підготовленості старшокласниць. Під час аналізу літературних джерел (Павленко, 2016; Кренделєва, 2015; Шевців, 2019) було засвідчено, що багато дівчат старшої школи зацікавлені сучасними напрямами оздоровчої фізичної культури, які допомагають не лише покращити фізичну підготовленість і зовнішній вигляд, але й перебувати в гармонії з собою та навколишнім середовищем.

Відповідно до мотивації, стану здоров'я та функціональних можливостей дівчат старшої школи, а також ураховуючи вимоги сучасної програми фізичного виховання 10-11 класів, розробку авторської програми здійснювали з оздоровчо-кондинційною спрямованістю, яка передбачала зниження ризику розвитку захворювань, а також включала в себе психічний, фізичний та духовний компоненти, що спрямовані на корекцію психоемоційного стану та фізичної підготовленості дівчат старшої школи.

Ментальним фітнесом прийнято вважати оздоровчі практики та різноманітні методики фізичної культури, які можуть об'єднати в собі такі основи, як: дух, душу і тіло. Назва ментального фітнесу також зустрічається, як програми (M ind $\&$ Body) «Розумне Тіло». Їх відносять до «м'якого фітнесу», вони набули популярності у XXI ст. Такі програми Mind \& Body - допомогають у покращенні психічного і фізичного здоров'я, знятті стресу, позбавлення від багатьох хвороб. Ментальний фітнес - один із найбезпечніших видів тренування, який включає в себе вправи на релаксацію, вправи на розтягування м'язів, а також рівновагу та дихання. Немає ніяких інших вправ, які 6 надавали настільки «м'яку» дію на тіло, одночасно зміцнюючи його (Синиця, 2018, с. 228).

Належать до таких програм стретчинг, програми Пілатеса, та інші, у яких застосовано принципи східних оздоровчих систем.

Виходячи з цієї концепції, нами була запропонована оздоровчорекреаційна програма для дівчат старшої школи, що включає в себе процес гармонійного розвитку фізичних якостей, підвищення рівня фізичної підготовленості за допомогою використання таких засобів ментального фітнесу, як стретчинг і пілатес, та спрямована на корекцію психоемоційного стану старшокласниць, для досягнення гармонії між фізичним, психічним і духовним компонентами. 
Запропонована нами оздоровчо-рекреаційна програма складалася 3 трьох частин: підготовчої, основної та заключної. Структура занять у запропонованій оздоровчо-рекреаційній програмі включала в себе диференційоване дозування фізичних навантажень. Крім того, це забезпечило можливість комплексного використання напрямів та засобів ментального фітнесу в процесі фізкультурно-оздоровчих занять.

При розробці оздоровчо-рекреаційної програми передбачалося дотримання методів оздоровчого тренування та фізичного виховання, повного переліку методичних принципів, диференціація в дозуванні обсягу фізичного навантаження для дівчат старшої школи.

Слід зазначити, що важливе місце в побудові оздоровчорекреаційної програми має урахування специфічного впливу фізичних вправ на організм, його призначення полягає в розвиткові гнучкості, зміцненні м'язів та поліпшенні психоемоційного стану старшокласниць. У зв'язку з цим при плануванні оздоровчих занять слід ураховувати чергування спрямованості впливу навантажень. Задля вирішення завдань дослідження оздоровчо-рекреаційна програма передбачала не тільки комплексний вплив на вдосконалення рівня розвитку фізичної підготовленості дівчат старшої школи, а й паралельно дозволила перебувати в гармонії з самим собою.

Таблиця 1

\section{Структурно-логічна схема побудови оздоровчо-рекреаційної програми}

\section{для дівчат старшої школи}

Мета: підвищення рівня фізичної підготовленості та корекція психоемоційного стану

Завдання: удосконалення рівня розвитку фізичної підготовленості дівчат старшої школи, збільшення рухової активності, зниження ризику розвитку захворювань, покращення латентної можливості реалізації тілесності

\begin{tabular}{|c|c|c|}
\hline \multicolumn{3}{|c|}{ Періоди } \\
\hline Підготовчий період & Основний період & Підтримуючий \\
\hline $\begin{array}{l}\text { Адаптація організму } \\
\text { до фізичних } \\
\text { навантажень }\end{array}$ & $\begin{array}{l}\text { Удосконалення та розвиток фізичних } \\
\text { якостей, підвищення рівня фізичної } \\
\text { підготовленості, } \\
\text { психічного стану }\end{array}$ & $\begin{array}{l}\text { Збереження } \\
\text { досягнутого рівня у } \\
\text { психічному стані та } \\
\text { фізичної } \\
\text { підготовленості } \\
\text { дівчат }\end{array}$ \\
\hline
\end{tabular}

Засоби: вправи з використанням спеціального обладнання (ізотонічне кільце, гумова стрічка, Фітбол (Fitball), тренажери - жимстік (gymstick, gym stick) та арка)

\begin{tabular}{|c|c|c|c|}
\hline \multicolumn{3}{|c|}{ Методи: } \\
\hline рівномірний & повторний & перемінний & інтервальний \\
\hline $\begin{array}{l}\text { Результат: підвищення рівня фізичної підготовленості та покращення психічного стану } \\
\text { старшокласниць }\end{array}$
\end{tabular}


Розроблена нами оздоровчо-рекреаційна програма залежно від періодів передбачала три етапи реалізації (підготовчий, основний та підтримуючий), рекомендованих Т. Ю. Круцевич (Круцевич, 2003, с. 137139). Завдання підготовчого періоду полягали у збільшенні можливостей основних функціональних систем, підвищенні рівня загальної фізичної підготовленості, навчання техніці виконання вправ.

Перехід до нового етапу супроводжується зміною кількості та послідовності виконаних вправ, спрямованістю їх взаємодії, тривалості окремих блоків занять, інтенсивністю та обсягом навантаження.

Для розв'язання однієї із задач нашої роботи нами були проведені експериментальні дослідження, за показниками сили, швидкості, витривалості, гнучкості та спритності ми мали змогу всебічно характеризувати рівень розвитку фізичної підготовленості дівчат старшої школи. Експериментальні дослідження здійснювались протягом 2018 2019 навчального року та були проведені на базі загальноосвітньої школи № 15 міста Суми, де була сформована експериментальна група дівчат $(\mathrm{E}, \mathrm{n}=27)$, де основною формою проведення занять були секційні заняття в школі за запропонованою програмою три рази на тиждень. Контрольні дослідження проводилися також на базі загальноосвітньої школи № 15 міста Суми - контрольна група дівчат ( $\mathrm{k}, \mathrm{n}=28)$, мала два уроки фізичної культури та додатково відвідували секційні заняття з різних видів спорту три рази на тиждень. Кількість та тривалість занять на тиждень в усіх групах дівчат, що приймали участь в експерименті, була однаковою. Загальна кількість старшокласниць, що брали участь у дослідженні, становила 55 осіб. Контрольні та експериментальні групи дівчат були сформовані таким чином, що за рівнем фізичної підготовленості вони вірогідно не відрізнялися на початку експерименту ( $>>0,05)$. Оцінка рівня фізичної підготовленості дівчат старшої школи здійснювалася за Державними тестами й нормативами оцінки фізичної підготовленості школярів.

Оцінка рівня фізичної підготовленості старшокласниць відносно державних нормативних стандартів показала, що на початку педагогічного експерименту в більшості школярок як контрольної, так і експериментальної групи, показники фізичної підготовленості відповідають рівню нижче середнього.

3 метою визначення впливу розробленої оздоровчо-рекреаційної програми на фізичну підготовленість старшокласниць нами було проведене повторне дослідження рівня розвитку фізичних якостей. За час проведення педагогічного експерименту в експериментальній групі відбулися статистично-вірогідні зміни $(p<0,05)$ показників фізичної підготовленості.

Як видно з табл. 2, результати тестуванні «Нахил тулуба вперед» в групі Е дівчат становлять 13,60 \pm 4,76 см, що на 44,11 \% вище, аніж на початковому етапі досліджень; у групі К дівчат - 8,18 \pm 4,45см, що на 
11,49 \% вищі від вихідних. Позитивна динаміка у групі Е дівчат, порівняно 3 групою К, свідчить про вірогідність різниці $(p<0,001)$.

Таблиця 2

\section{Результати тестування фізичної підготовленості дівчат старшого} шкільного віку за Державними тестами до та після експерименту, $\bar{x} \pm S_{x}$

\begin{tabular}{|c|c|c|c|c|c|c|c|}
\hline Тест & $\lceil\mathrm{p}$. & $n$. & До експерименту & $P$ & $\begin{array}{c}\text { Після } \\
\text { експерименту }\end{array}$ & $\begin{array}{c}\text { При- } \\
\text { ріст у } \\
(\%)\end{array}$ & $P$ \\
\hline \multirow{2}{*}{$\begin{array}{l}\text { Нахил тулуба } \\
\text { вперед }\end{array}$} & K & 28 & $7,42 \pm 0,85$ & & $8,18 \pm 4,45$ & 11,49 & \\
\hline & $\mathrm{E}$ & 27 & $7,6 \pm 0,89$ & $>0,05$ & $13,60 \pm 4,76$ & 44,11 & $<0,001$ \\
\hline \multirow[t]{2}{*}{ Біг $60 M$} & K & 28 & $10,89 \pm 1,09$ & & $11,07 \pm 0,62$ & 1,63 & \\
\hline & $E$ & 27 & $10,68 \pm 1,1$ & $>0,2$ & $10,28+0,4$ & 3,75 & $<0,001$ \\
\hline \multirow{2}{*}{$\begin{array}{l}\text { Згинання та } \\
\text { розгинання рук }\end{array}$} & K & 28 & $8,26 \pm 0,97$ & & $8,48 \pm 3,14$ & 2,59 & \\
\hline & $E$ & 27 & $8,09 \pm 0,97$ & $>0,1$ & $11,26 \pm 4,75$ & 28,15 & $<0,05$ \\
\hline \multirow{2}{*}{$\begin{array}{l}\text { Стрибок у } \\
\text { довжину } \\
3 \text { місця } \\
\end{array}$} & K & 28 & $140,89 \pm 7,5$ & & $141,37 \pm 7,47$ & 0,34 & \\
\hline & E & 27 & $142,2 \pm 7,25$ & $>0,2$ & $161,9 \pm 7,75$ & 12,16 & $<0,001$ \\
\hline \multirow[t]{2}{*}{ Крос 1500 M } & K & 28 & $9,28 \pm 0,56$ & & $9,08 \pm 0,58$ & $-2,16$ & \\
\hline & $\mathrm{E}$ & 27 & $9,25 \pm 0,59$ & $>0,2$ & $8,44 \pm 0,55$ & 8,76 & $<0,001$ \\
\hline \multirow{2}{*}{$\begin{array}{l}\text { Піднімання в сід за } \\
1 \text { хв }\end{array}$} & K & 28 & $23,3 \pm 2,77$ & & $25,15 \pm 4,22$ & 7,36 & \\
\hline & E & 27 & $23,47 \pm 2,52$ & $>0,2$ & $30,91 \pm 6,21$ & 24,06 & $<0,001$ \\
\hline \multirow{2}{*}{$\begin{array}{l}\text { Човниковий біг } 4 \times 9 \\
\text { м }\end{array}$} & K & 28 & $11,86 \pm 0,69$ & & $11,95 \pm 0,65$ & $-0,75$ & \\
\hline & E & 27 & $12,06 \pm 0,63$ & $>0,1$ & $11,46 \pm 0,78$ & 4,975 & $<0,005$ \\
\hline
\end{tabular}

Після впровадження оздоровчо-рекреаційної програми ми отримали такі результати і тесті «біг 60 м», показники яких свідчать, що покращення швидкості у групі К становить лише $1,63 \%$, у групі $\mathrm{E}-3,75 \%$, а значення дорівнюють $11,07 \pm 0,62$ с в групі К дівчат, 10,28 $\pm 0,4$ с в групі Е дівчат. Результати в групі Е вірогідно ( $p<0,001)$ вищі, порівняно з групою К дівчат.

Результати щодо тестування сили «Згинання та розгинання рук» становлять: у групі K - 8,48+3,14 разів, у групі $\mathrm{E}-11,26+4,75$ разів. Приріст показників сили у групі K складає $2,59 \%$, у той час як у групі $\mathrm{E}$ дівчат показник сили збільшився на 28,15\% (табл. 2).

3 метою більш ефективного розвитку силових якостей у запропонованій нами оздоровчо-рекреаційній програмі ми дотримувалися основних принципів тренування: поступового збільшення навантаження, раціонального чергування роботи й відпочинку, спрямованості занять, рівномірності навантаження всіх м'язових груп, вибору оптимальних навантажень, що, на нашу думку, спричинило відповідні покращення показників сили за 
результатами тесту «згинання та розгинання рук в упорі лежачи». Отже, у результаті експерименту зафіксовано вірогідні зміни в показниках сили в групі Е дівчат ( $<<0,05)$, порівняно з групою $\mathrm{K}$ дівчат. Після проведеного педагогічного експерименту ми спостерігали динаміку до покращення швидкісно-силових якостей за тестом «стрибок у довжину з місця». У групі К дівчат приріст після експерименту становить 0,34 \%, у групі E - 12,16 \%.

За тестом «біг на 1500 м» ми визначили рівень загальної витривалості у дівчат 15-17 років. їі динаміка розвитку дещо відрізнялася від інших рухових якостей: у групі Е дівчат результат складає 8,44 \$0,55 хв., що на 8,76 \% вище, ніж на початковому етапі (табл. 2). Щодо групи К, то показники витривалості в дівчат навіть погіршилися на 2,16 \%, порівняно 3 вихідним тестуванням. Такі результати тестування пояснюються тим, що витривалість, як фізична якість, має гетерохронний характер розвитку. Динаміка розвитку загальної витривалості в дівчат має свій характер. Високі темпи приросту припадають на період від 14 до 16 років, а потім їі рівень підвищується повільно й може навіть знижуватися. Аналіз результатів показує достовірну різницю $(p<0,001)$ показників витривалості, у групі Е дівчат, вищий рівень витривалості, аніж у групі К дівчат.

Позитивними змінами в кінці наших досліджень характеризується тест «піднімання в сід за 1 хвилину»: у групі К дівчат, які займалися за шкільною програмою на базі школи № 15 міста Суми та додатково відвідували секційні заняття з різних видів спорту, приріст становить 7,36 $\%$, у групі E - 24,06 \%, які займалися за шкільною програмою на базі школи № 15 міста Суми й відвідували заняття за запропонованою оздоровчорекреаційною програмою. Отримані результати в групі $\mathrm{E}$, порівняно 3 групою К, свідчать про вірогідну різницю ( $<0,001)$.

Як видно з табл. 2, отримані результати після проведення експериментальних досліджень за тестом «човниковий біг 4 × 9 м» дають можливість констатувати, що у групі К дівчат показники спритності погіршилися на 0,75 \%, порівняно з вихідним рівнем, натомість приріст показників у групі Е складає 4,9 \%.Темпи приросту в групі Е дівчат, порівняно з групою К, свідчать про статистично-вірогідну різницю між результатами експерименту ( $p<0,005)$.

Аналіз тестування фізичної підготовленості старшокласниць свідчить, що під впливом занять за розробленою нами програмою відбулися статистично-вірогідні зміни в експериментальній групі дівчат. Оцінка рівня фізичної підготовленості старшокласниць відповідно до Державних тестів і нормативів показала, що в кінці наших досліджень в експериментальній групі дівчат старшої школи показники фізичної підготовленості відповідали середньому рівню, натомість у контрольній групі позитивних змін не було зафіксовано. 
Для перевірки ефективності розробленої рекреаційно-оздоровчої програми для покращення фізичного і психо-емоційного стану, за методикою Г.В.Ложкіна та А. Ю. Рождественського (Ложкін, 2004, с. 27), нами було проведене дослідження, яке дозволило визначити рівень саморефлексії тілесного потенціалу та спосіб життєвого самовизначення учнів старшої школи.

Г. В. Ложкін та А.Ю. Рождественський у своїх дослідженнях розширюють межі поняття «тіло», під яким мається на увазі не натуральне (природне) тіло з його функціями, яке охоплюється поняттям «організм» (об'єктивна реальність, яка підпорядковується біологічним закономірностям), а тіло як «жива форма», як суб'єктивна реальність (соціальне культурне тіло) (Ложкін та Рождественський, 2005, с. 41).

Опитувальник саморефлексії тілесного потенціалу містив 23 пункти, аналіз відповідей на які дозволив розділити учнів старшої школи за трьома типами репрезентації тілесного потенціалу: вітальним, конформним, особистісним.

Експериментальний дослід проводився в два етапи. На першому етапі експерименту між контрольною та експериментальними групами дівчат статично-вірогідної різниці не виявлено. Разом виявлено 25,93 \% дівчат із вітальним типом. Цей тип відносить школярів до самовпевнених осіб, які повністю задоволені своїм соціальним статусом у суспільстві, мало схильні до саморегуляції та самоаналізу. Прогноз майбутнього для цих респондентів обмежується такими перспективами - оволодінням професією як засіб задоволення матеріальних потреб. Засобом дотримання сучасного стану $€$ цілі майбутнього, що позбавлені дійсності та будь-якої аргументованості.

Найчисельніша група респондентів виявлений конформний тип ( $n=16$, або 59,26 \%). Головні якості, які відносить до комформного типу $\epsilon$ підвищенна тривожність, низька самооцінка та виразна критічність до своєї особистості, висока увага до стереотипів та вказівок соціального оточення, знижена активність, схильність приписувати власні невдачі на зовнішні фактори, що робить цей тип залежниками від соціальних обставин,

Характерною рисою цього типу є підвищена ситуативна тривожність, стримана критичність відносно своїх можливостей, виразна орієнтація на соціальну уяву та сучасні стереотипи, низька самоактивність та схильність приписувати власні невдачі соціальним обставинам, що робить представників цього типу залежними від зовнішніх ситуацій.

Після проведення аналізу, найменшу групу склали дівчата 3 особистісним типом саморегуляції тілесного потенціалу ( $\mathrm{n}=4$, або 14,81\%). Характерною рисою, що виокремлює цю репрезентацію, $€$ підвищена інтенсивність та активність: дівчата позитивно сприймають власне Я, впевнені в досяжності своєї мети та готові до корекції невдач з-за допомогою своїх можливостей та активності. 
Таблиця 3

Результати впливу розробленої рекреаційно-оздорочої методики на рівень саморефлексії тілесного потенціалу учнями старшої школи $(\mathbf{n}=55)$

\begin{tabular}{|c|c|c|c|c|c|c|c|}
\hline \multirow{2}{*}{\multicolumn{2}{|c|}{ Групи }} & \multicolumn{2}{|c|}{ Вітальний } & \multicolumn{2}{c|}{ Конфорний } & \multicolumn{2}{c|}{ Особистісний } \\
\cline { 2 - 8 } & Кількість & $\%$ & Кількість & $\%$ & Кількість & $\%$ \\
\hline \multirow{2}{*}{ К } & До & 9 & 32,14 & 13 & 46,43 & 6 & 21,43 \\
\cline { 2 - 8 } & Після & 8 & 28,57 & 13 & 46,43 & 7 & 25 \\
\hline \multirow{2}{*}{ Е } & До & 7 & 25,93 & 16 & 59,26 & 4 & 14,81 \\
\cline { 2 - 8 } & Після & 5 & 18,52 & 13 & 48,15 & 9 & 33,33 \\
\hline
\end{tabular}

Після проведеного досліду, що пов'язаний із перевіркою ефективності оздоровчо-рекреаційної технології на основі застосування ментального фітнесу, нами було визначено динамічність у кількості учнів старшої школи з різними типами репрезентації тілесного потенціалу, де відзначені позитивні зміни в експериментальних групах під впливом запропонованого дослідного фактору.

Як видно з табл. 3, серед дівчат експериментальної групи ( $\mathrm{E}, \mathrm{n}=27)$, під впливом занять по запропонованій методиці на 18,52 \% підвищилась кількість респондентів особистісного типу за рахунок зниження кількості школярів, які відносяться до вітальної репрезентації на 10,74 \% та зменшення кількості учнів, які мають конформну репрезентацію на 7,41 \%. Тоді як у контрольній групі дівчат $(K, \mathrm{n}=28)$, які навчалися за шкільною програмою, яка складалась 3 уроків фізичної культури та трьох позаурочних занять на тиждень, зміни не відбувалися.

Узагальнюючи отриманні дані, можна констатувати, що під впливом занять за розробленою оздоровчо-рекреаційною програмою відбулися значні позитивні зміни у ставленні старшокласників до власного тілесного потенціалу. Збільшилась кількість дівчат, які більш сприймають власне Я, проявляють упевненість у досягненні мети, готовність до подолання невдач, за рахунок своїх можливостей та самоактивності. Наведені результати експерименту свідчать про доцільність упровадження авторської програми у фізичного виховання учнів старшої школи.

\section{Висновки.}

1. Проаналізувавши наукову та методичну літературу, можна свідчити, що рухова діяльність учнів старшої школи має тенденцію до зниження. Весь вільний час старшокласники займаються навчанням у сидячому положенні, ведуть малорухливий спосіб життя, запам'ятовують велику кількість інформації, постійно знаходяться в стресовій ситуації. 
Відносно до цього, потрібно більш широко використовувати всі можливості для забезпечення максимального розвитку фізичної діяльності, зміцнення здоров'я та популяризації здорового способу життя серед учнів старших класів. Для того, щоб відкоригувати фізичний і психоемоційний стан школярів, необхідні фізичні навантаження, що позитивно впливатимуть як і на фізичне, так і на психічне розслаблення учнів.

2. Виходячи з цієї концепції, нами була запропонована оздоровчорекреаційна програма для дівчат старшої школи, що включає в себе процес гармонійного розвитку фізичних якостей, підвищення рівня фізичної підготовленості на основі застосування засобів ментального фітнесу, та спрямована на корекцію психоемоційного стану старшокласниць, для досягнення гармонії між фізичним, психічним і духовним компонентами.

3. У дівчат старшої школи 15-17 років експериментальна група впродовж навчального року відбулися статистично достовірні $(p<0,05)$ зміни порівняно з контрольною групою за всіма тестами. Заняття за рекреаційнооздоровчою програмою сприяли покращенню показників загальної фізичної підготовленості в групі Е на 18 \%. Натомість у групі К показники покращилися лише на 3 \% та відповідають середньому рівню.

4. Під впливом занять за розробленою рекреаційно-оздоровчою програмою збільшилася кількість дівчат старшої школи, що проявляють упевненість у досягненні мети, готовність до подолання невдач, за рахунок самоактивності та своїх можливостей.

Перспектива подальшого наукового дослідження полягає в дослідженні впливу програми на рівень розумової працездатності дівчат старшої школи засобами ментального фітнесу.

\section{ЛITEPATУРА}

Андрєєва, О. В. (2015). Теоретико-методологічні засади рекреаційної діяльності різних груп населення. Теорія і методика фрізичного виховання і спорту, 29-43 (Andrieieva, O. V. (2015). Theoretical and methodological foundations of recreational activity of different population groups. Theory and M ethods of Physical Education and Sport, 29-43).

Ващук, Л. М. (2016). Алгоритм побудови індивідуальних фітнес-програм для самостійних занять старшокласниць. Фізичне виховання, спорт і культура здоров'я у сучасному суспільстві, 20-25 (Vashchuk L. M. (2016). An algorithm for constructing individual fitness programs for independent high school students. Physical Education, Sports and Health Culture in Modern Society, 20-25).

Державні тести і нормативи оцінки фрізичної підготовленості населення України: Постанова Кабінету міністрів України від 15 січня 1996 р., 80-22 (State tests and standards of assessment of physical fitness of the population of Ukraine: Resolution of the Cabinet of M inisters of Ukraine of January 15, 1996, 80-22).

Дубинська, О. Я. (2016). Сучасні фрітнес-технології у фізичному вихованні учнівської та студентської молоді: проектування, розробка та особливості. Суми: Вид-во СумПДУ імені А. С. Макаренка, 351 (Dubinska, О. Ya. (2016). Modern fitness technologies in physical education of student and student youth: design, development and features. Sumy: A. S. M akarenko SSPU, 351). 
Игонин, А. С. Проект: «Психологчческая подготовка школьников к ЕГЭ». Режим доступа: http://www.pfo.ru/?id=21319 (Igonin, A. S. Project: "Psychological preparation of schoolchildren for EGE". Retrieved from: http://www.pfo.ru/?id=21319).

Кренделєва, В. У. (2015). Вплив оздоровчого фітнесу на рівень фізичної підготовленності учнів старших класів. Науковий журнал «Молодий вчений», 175-178 (Kendelieva, V. V. (2015). The influence of health fitness on the level of physical fitness of senior students. Scientific Journal "Young Scientist", 175-178).

Круцевич, Т. Ю. (2019). Міжнародний досвід організації оздорочо-рекреаційної діяльності школярів у вільний час. Науковий журнал «Молодий вчений», 152-156 (Krutsevich, T. Yu. (2019). International experience of organizing recreational and recreational activities of students in their free time. Scientific Journal "Young Scientist", 152-156).

Круцевич, Т. Ю. (2003). Теория и методика физического воспитания. Том 2. Олимипийская литература: Киев, 137-139 (Krutsevych, T. Yu. (2003). Theory and methodology of physical education, Vol. 2. The olympic literature: Kyiv, 137-139.

Ложкин, Г. В. (2005). Психосемантический анализ структуры представлений спортсменов о теле (телесности). Наука в олимпийском спорте, 41-46 (Lozhkin, G. V. (2005). Psychosemantic analysis of the structure of athletes' perceptions of the body (corporeality). Science in Olympic Sports, 41-46).

Ложкин, Г. В. (2004). Феномен телесности в я-структуре старшеклассников и содержание их жизненных проэктов. Психологический журнал, 27 - 33. (Lozhkin, G. V. (2004). The phenomenon of physicality in the self-structure of high school students and the content of their life projects. Psychological Journal, 27-33).

Павленко, І. О. (2016). Застосування засобів оздоровчого фітнесу для корекції ваги дівчат старшого шкільного віку. Слобожанський науково-спортивний вісник, 6973 (Pavlenko, I. O. (2016). Application of fitness tools for weight correction of older school age girls. Slobozhansk Scientific and Sport Bulletin, 69-73).

Синиця, Т. О. (2019). Корекція фрізичного стану жінок першого зрілого віку засобами оздоровчої аеробіки та ментального фітнесу. Львів. держ. ун-т фіз. культури ім. І. Боберського (Sinitsa, T. О. (2019). Correction of physical condition of women of the first mature age by means of health aerobics and mental fitness. Lviv. state. University of Phys. culture named after I. Bobersky).

Синиця, Т. О. (2018). Ментальний фітнес як одиніз сучасних напрямів оздоровчої фрізичної культури (Sinitsa, Т. О. (2018). Mental fitness as one of the modern trends of health-improving physical culture).

Шевців У. С. (2019). Технологія впровадження оздоровчих видів гімнастики у фізичне виховання старшокласниць (на прикладі шейпінгу). Львів. держ. ун-m фіз. культури, 18 с. (Shevtsov U. S. (2019). Technology of introduction of healthimproving gymnastics in physical education of high school students (on the example of shaping). Lviv. state. University of Phys. culture, p. 18).

\section{PEЗЮME}

Дубинская Оксана, Марыченко Ольга, Беля Анастасия. Влияние рекреационнооздоровительной программы на физическую подготовленность и психическое состояние девушек старших классов на основе применения ментального фитнеса.

Разработана оздоровительно-рекреационная программа занятий на основе применения средств ментального фитнеса, направленная на коррекцию физической подготовленности и улучшения психического состояния девушек старших классов. Методы: анализ и обобщение научно-методической литературы, психологопедагогические методы, педагогический эксперимент, тестирование, методы 
математической статистики. Нами изучено влияние разработанной программы на развитие двигательных способностей старшеклассницами и исследованы особенности проектирования их жизненных перспектив. Под влиянием занятий по разработанной оздоровительно-рекреационной программе на основе применения средств ментального фитнеса произошли статистически достоверные положительные изменения в их отношении к собственному телесному потенциалу, а также в показателях физической подготовленности старшеклассниц.

Ключевые слова: старшеклассницы, рекреационно-оздоровительная программа, ментальный фитнес, двигательные способности, саморефллексия телесного потенциала.

\title{
SUMMARY
}

Dubynska Oksana, Marychenko Olha, Bielia Anastasila. Influence of recreational and wellness program on physical fitness and mental state of high school girls on the basis of mental fitness.

A wellness and recreational training program based on the use of mental fitness has been developed, aimed at correcting physical fitness and improving mental state of high school girls. Methods: analysis and generalization of scientific-methodological literature, psychologicalpedagogical methods, pedagogical experiment, testing, methods of mathematical statistics. We have studied the impact of the designed program on the high school students' motor skills development and explored the peculiarities of designing their life prospects.

After the experiment, which is related to testing the effectiveness of recreational technology based on the use of mental fitness, we determined the dynamics in the number of high school students with different types of representation of bodily potential, which showed positive changes in the experimental groups under the influence of the proposed experiments. It can be stated that under the influence of the classes on the developed wellness and recreation program there were significant positive changes in the attitude of the high school students to their own physical potential. The number of girls who are more receptive to their own self has increased, showing confidence in achieving the goal, willingness to overcome failure, at the expense of their abilities and self-activity. The results of the experiment testify to the expediency of introducing the author's program in the physical education of high school students.

Key words high school students, recreational and wellness program, mental fitness, motor skills, self-reflection of physical potential.

UDC 304:316

\author{
Izabela Kettyk-Zaborouska \\ Uniwersytet Jana Kochanowskiego w Kielcach Filia \\ w Piotrkowie Trybunalskim \\ ORCID ID 0000-0003-4120-6446 \\ DOI 10.24139/2312-5993/2019.08/066-077
}

\section{ETHCALASPECTSOF SOQALNETWORKNG.}

The article poses the question about the importance of social networking in the lives of students. Attention is drawn to the possibility of a certain form of addiction to social networks. The analysis of the research results has allowed to formulate the following conclusions: students 